UDK 81'272:373.3.016

DOI https://dx.doi.org/10.21857/m16wjceko9 Izvorni znanstveni članak Rukopis primljen 28. IX. 2020.

Bojana Schubert

Prihvaćen za tisak 8. II. 2021.

Zavod za lingvistička istraživanja

Hrvatska akademija znanosti i umjetnosti

Ulica književnika Ante Kovačića 5, HR-10000 Zagreb

bmarkovi@hazu.hr

\title{
NI MED CVETJEM NI PRAVICE! OBRADA NESTANDARDNOG LEKSIKA U HRVATSKIM ČITANKAMA I ŠKOLSKIM RJEČNICIMA* *****
}

U radu se analizira odnos školskih rječnika hrvatskoga jezika prema nestandardnom leksičkom sloju koji je dijelom hrvatske književnosti, lektire, a onda i čitanki za nastavni predmet Hrvatski jezik. Dolazi se do zaključka da je u hrvatskim čitankama nestandardni leksik hrvatskoga jezika često obrađen neprecizno, bez velikog mara, a u školskim je rječnicima uglavnom preskočen, neobrađen, što upućuje na zaključak da postojeći školski rječnici hrvatskoga jezika ne ispunjavaju u potpunosti svoju svrhu jer ne opisuju hrvatski jezik s kojim se učenik susreće u školskome gradivu - tijekom nastave ili čitajući lektiru - nego p(r)opisuju ono što njihovi autori/sastavljači smatraju standardnim hrvatskim jezikom.

* Rad posvećujem dr. Jeli Maresić, umirovljenoj upraviteljici Zavoda za lingvistička istraživanja, uz koju me vežu lijepa sjećanja.

** Dio rezultata analize provedene za ovaj rad prezentiran je na konferenciji 2 nd International Conference on Sociolinguistics (ICS-2) održanoj 2018. godine u Budimpešti.

*** Zahvaljujem recenzentima na iznimno korisnim savjetima i komentarima koji su doveli do toga da rad u konačnici bude bolji. 


\section{Uvod}

Svaki se sastavljač rječnika na početku svoga projekta pita s kojim ciljem ili svrhom sastavlja rječnik, komu je taj rječnik namijenjen i na kojem će se korpusu temeljiti. Sastavljač ili leksikograf svjestan je da u jedan, osobito tiskani rječnik, ne stane sav leksički asortiman određena jezika. Stoga on najprije planira korpus iz kojega će vaditi leksičke potvrde, određuje približan broj natuknica koje namjerava obraditi i način na koji će ih obrađivati, što uvelike ovisi o tome komu je rječnik namijenjen. Također, svaki leksikograf, kao uostalom i svaki istraživač, djeluje unutar određena povijesno-društvenog i kulturnog okvira nastalog na temelju svojih uvjerenja i ideoloških pozicija (usp. Katnić-Bakaršić 2012:7).

U ovom će se radu pobliže analizirati abecedariji školskih rječnika hrvatskoga jezika koji bi prema definiciji trebali sadržavati leksik iz školskoga gradiva s kojim se susreću hrvatski učenici tijekom osnovnoškolskog i srednjoškolskog obrazovanja. U radu će se nastojati dati odgovor na pitanje je li tomu tako i zašto jest ili nije, te koja je ideologija u pozadini leksikografovih odabira natuknica za školske rječnike.

U nastavnim ćemo poglavljima govoriti najprije o teorijskim postavkama na kojima se temelji ovaj rad te dati sažeti prikaz stavova o nestandardnom leksiku najprije u nastavnom planu i programu te kurikulumu koji su mogli utjecati na sastavljače školskih rječnika, a zatim ćemo se osvrnuti na stavove o istoj temi koji se mogu iščitati iz predgovora školskih rječnika hrvatskoga jezika. Slijede poglavlja o metodologiji i ciljevima istraživanja, rezultatima analize te rasprava i zaključak.

\section{Teorijske postavke}

Temom se ovaj rada smješta u domenu obrazovne lingvistike, discipline koja objedinjuje lingvističke i sociološke metode s ciljem sveobuhvatnoga proučavanja pitanja povezanih s jezikom i obrazovanjem (Spolsky 1978, 2008; Hornberger 2008). U radu polazimo od pretpostavke da obrazovni sustav igra važnu ulogu u oblikovanju jezične politike i jezičnog planiranja pojedine zemlje (Bourdieu 1991:48). U tom smislu pogledat ćemo kakvi su stavovi prema jezičnoj raslojenosti, konkretno nestandardnom leksiku hrvatskoga jezika, u službenom Nastavnom planu i programu i Kurikulumu za predmet Hrvatski jezik. Objavljeni 2006., odnosno 2011. godine, ti su dokumenti mogli utjecati na sastavljače dvaju školskih rječnika hrvatskoga jezika. S nastavnim planovima i programima trebali bi biti usklađeni školski udžbenici dio kojih (hrvatske čitanke) ulaze 
u fokus naše analize. U samoj analizi posebnu ćemo pažnju posvetiti rječniku koji je najrecentniji i koji jedini ima preporuku Ministarstva znanosti, obrazovanja i sporta za uporabu u osnovnim i srednjim školama (Anićev školski rječnik hrvatskoga jezika iz 2015).

Našim istraživanjem želimo pokazati ima li u školskim rječnicima purizma kako ga definira Thomas (1991:12): »[Purizam je] manifestacija želje dijela jezične zajednice da sačuva jezične oblike, ili da ih odbaci, narodne, strane ili druge nepoželjne elemente (uključujući one koji dolaze iz dijalekata, sociolekata i stilova/registara istoga jezika). Može biti usmjeren na sve jezične razine, a najviše na leksik. Povrh svega, purizam je oblik kodifikacije, kultiviranja i planiranja standardnog jezika. « Drugim riječima, zanima nas jesu li u školskim rječnicima obrađene sve riječi koje se nalaze u promatranom dijelu školskih materijala, neovisno o tome kojem registru pripadaju, ili nisu, a onda zašto nisu.

Nadalje želimo ispitati pretpostavku da su školski rječnici hrvatskoga jezika sastavljani pod utjecajem ideologije standardnog jezika. Riječ je o stavovima prema kojima je standardni jezik kao davno utemeljen kodificiran varijetet, promoviran u sustavu obrazovanja, gramatikama, čitankama i rječnicima, onaj koji određuje što je točno i zabranjuje ono što se ne bi trebalo govoriti i pisati (prema Milroy i Milroy 1992:23). Ta ideologija za sobom vuče niz reperkusija, od brisanja i tajenja nestandardnih oblika u jezičnim priručnicima i rječnicima, do omalovažavanja govornika nestandardnih varijeteta i sl. (usp. Irvine i Gal 2000:38).

Ulogu školskih rječnika hrvatskoga jezika držimo važnom u hrvatskoj jezičnoj politici i u jezičnome planiranju jer se rječnik općenito uzima kao jezični autoritet: »Kako je Biblija sveta Knjiga, tako je rječnik postao sekularna Knjiga, izvor autoriteta, model ponašanja i simbol jedinstva u jeziku« (Algeo 1989:29). ${ }^{2}$ Isti autor smatra da se »izostavljanje riječi [u rječniku] uzima kao tvrdnja da 'te riječi nema u jeziku'; unos riječi (natuknice) smatra se pečatom odobrenja «3 (Algeo 1989:32; v. i Béjoint 2000:121-122; Gorjanc 2017:43).

1 [Purism is] "manifestation of a desire on the part of a speech community (or some section of it) to preserve a language form, or rid it of, putative foreign elements or other elements held to be undesirable (including those originating in dialects, sociolects and styles of the same language). It may be directed at all linguistic levels but primarily the lexicon. Above all, purism is an aspect of the codification, cultivation and planning of standard language .

2 »As the Bible is the sacred Book, so the dictionary has become the secular Book, the source of authority, the model of behaviour, and the symbol of unity in language«.

3 "...the omission of a word is often taken as a statement that there is no such word in the language'; the entry of a word is perceived as a seal of approval«. 
U tom nas kontekstu zanima kakva je situacija u školskim rječnicima hrvatskoga jezika: jesu li i oni jezični arbitri koji odlučuju koje su riječi iz školskih materijala "prikladne" te njih obrađuju, ili su neutralan izvor informacija.

U povijesti hrvatske leksikografije nalazimo niz primjera u kojima se dio hrvatske leksičke građe svjesno izostavljao iz rječničkih abecedarija upravo zbog jezično-ideoloških razloga. ${ }^{4} \mathrm{U}$ drugim, osvještenijim, povijesnim trenucima to se pokušalo na neki način ispraviti. ${ }^{5}$

Kako se dosad nije pisalo o nomenklaturi školskih rječnika hrvatskoga jezika, cilj je ovoga rada ukazati na obuhvatnost ili neobuhvatnost te znanstvenost ili neznanstvenost njihova pristupa, u nadi da će naš uvid biti koristan leksikografskoj zajednici.

\section{1. Službeni dokumenti o nestandardnom leksiku u nastavi hrvat- skoga jezika}

U ovom ćemo se poglavlju osvrnuti na službene spise o temi nestandardnog leksika i jezičnih varijeteta u nastavi hrvatskoga jezika od 2006. do 2015. godine. Prije toga kratko ćemo spomenuti da su dosadašnja istraživanja pokazala da je za vrijeme Jugoslavije malen dio dijalektnog gradiva ulazio u službeni obrazovni program, a to se tek neznatno promijenilo nakon osamostaljenja Republike Hrvatske (Turza-Bogdan 2011:190).

U vrijeme obrade i objavljivanja školskih rječnika hrvatskoga jezika na snazi su bila dva službena dokumenta: Nastavni plan i program za osnovnu školu (dalje NPP) (Ministarstvo znanosti, obrazovanja i športa, 2006) i Nacionalni okvirni kurikulum (dalje NOK) (Ministarstvo znanosti, obrazovanja

4 Primjerice, u povijesni Akademijin rječnik hrvatskoga jezika uglavnom nisu ušli primjeri iz kajkavskoga književnog jezika (16.-19. stoljeće) (Daničić 1976:6-7); u Broz-Ivekovićev rječnik nisu ušli primjeri iz hrvatske književnosti, nego većinom iz štokavskoga narječja (Petrović 2006:467); u Benešićev književnojezični rječnik mahom nisu ušli kajkavski citati koji su dijelom korpusa novije hrvatske književnosti toga rječnika (Maresić i Schubert 2014; Schubert 2018).

5 Eklatantan je primjer Rječnik hrvatskoga kajkavskoga književnog jezika koji izlazi od 1984. naovamo, i u koji ulazi građa dopreporodne književnokajkavske provenijencije, ali i primjeri iz dijalektalne kajkavske književnosti ispisane u 20. stoljeću. Taj rječnik predstavlja svojevrstan kajkavski geto u koji se sklanja leksik koji je drugdje nepoželjan (vidi prethodnu bilješku). Vrijedi primijetiti da u naslovu toga rječnika stoji pridjev kajkavski uz hrvatski, kako bi se jasno naznačilo o kakvu je leksiku riječ. S druge strane, u naslovima mnogobrojnih rječnika hrvatskoga standardnog jezika, ili tek nekojeg njegova segmenta (npr. frazeoloških rječnika), stoji sintagma rječnik hrvatskoga jezika, kao da sadrže leksik iz svih hrvatskih varijeteta, bilo dijatopijski, bilo dijastratijski raslojenih, no kada ih otvorimo unutra nalazimo tek standardnojezični leksik. Poistovjećuju se dakle pojmovi hrvatski jezik i hrvatski standardni jezik. 
i športa, 2011).

NPP ističe sljedeće zadaće nastavnoga područja hrvatski jezik: »osposobljivanje učenika za uspješno snalaženje u svakodnevnim priopćajnim situacijama; ovladavanje jezičnim sredstvima potrebnim za uspješnu komunikaciju; osvješćivanje potrebe za jezičnim znanjem; suzbijanje straha od jezika; osvješćivanje razlika između standardnoga jezika i zavičajnih idioma; postupno usvajanje hrvatskoga jezičnog standarda« (NPP 2006:25). U cijelom je dokumentu vidljiv naglasak na učenju i brušenju hrvatskoga standardnog jezika, no zastupljene su i nestandardnojezične teme. Tako se u četvrtom razredu očekuje da će učenici »razlikovati književni jezik od zavičajnoga govora; odrediti svoj zavičajni govor u odnosu na jedno od tri narječja hrvatskoga jezika; usmeno i pisano komunicirati na svome zavičajnome govoru « (isto, 33). U petome razredu očekuje se da će učenici »razlikovati zavičajne idiome i književni jezik; osvijestiti postojanje različitih narodnih govora i potrebu njihova njegovanja; razvijati svijest o važnosti pravilnoga pisanja i govorenja hrvatskim književnim jezikom« (isto, 35). Tu su među izbornim sadržajima teme »Hrvatski govori: ikavski, ekavski, (i)jekavski i čitanje s razumijevanjem (književnih i neknjiževnih tekstova)《 te »Pripovijedanje zanimljivoga događaja jezikom moje bake i jezikom moje generacije« (isto, 35). U šestom razredu nestandardnojezične teme pronalazimo jedino među izbornim sadržajima, a u sedmom ih razredu nema. U osmom razredu predviđena je obrada obilježja hrvatskih narječja s obrazovnim postignućima: »razlikovati najvažnija obilježja svakoga hrvatskoga narječja i glavne prostore gdje se govore; razlikovati štokavsko narječje od hrvatskoga književnoga jezika; razumjeti odnos naziva hrvatski književni jezik i hrvatski standardni jezik, razlikovati ih « (isto, 47). Vrijedi spomenuti i temu: Razgovorni stil s obrazovnim postignućima: "zamjećivati obilježja razgovornoga stila; izdvajati iz razgovora posuđenice, žargonizme, lokalizme i dijalektizme; zamjećivati njihovu stilsku i obavijesnu vrijednost; zamjenjivati ih stilski neutralnim riječima i izrazima; primjereno se služiti razgovornim stilom i neverbalnim sredstvima u različitim komunikacijskim situacijama« (isto, 47).

U NOK-u je najviše pažnje posvećeno promicanju i razvijanju svijesti »o hrvatskom jeziku kao bitnomu čimbeniku hrvatskoga identiteta « te sustavnom njegovanju hrvatskoga standardnoga (književnog) jezika u svim područjima, ciklusima i svim razinama odgojno-obrazovnoga sustava (NOK 2011:22). Tek je u gimnazijama predviđeno da učenici uoče razlike između standardnoga govora i tekstova izgovorenih $u$ jezičnim registrima / varijetetima (isto, 101). 
Kako je Nastavni plan i program iz 2006. bio krovni školski dokument u vremenu nastajanja recentnijih školskih rječnika hrvatskoga jezika, na temelju iščitavanja njegova sadržaja možemo zaključiti da su u nastavi hrvatskoga jezika predviđene i nestandardnojezične teme - bilo da je riječ o dijastratijskoj ili dijatopijskoj raslojenosti hrvatskoga jezika. ${ }^{6}$ Sukladno tomu, ostvaraje NPP-a očekujemo pronaći i u udžbenicima pisanima nakon 2006. godine te $u$ hrvatskim čitankama iz kojih ćemo crpiti građu za našu analizu. ${ }^{7}$

\section{2. Školski rječnici}

O školskim rječnicima hrvatskoga jezika nije se dosad mnogo pisalo, a slična je situacija i u drugim zemljama (Béjoint 2000:40). Krenimo stoga redom, dajući na početku definiciju školskog rječnika uglednog francuskog leksikografa Henrija Béjointa (2010:47). Po njemu su rječnici za adolescente oni koji se izrađuju za školske potrebe, njihovi se abecedariji (popisi natuknica) temelje na školskim udžbenicima, dok natuknice u mikrostrukturnom smislu sadrže informacije koje su djeci potrebne za pisanje zadaća i praćenje nastave. ${ }^{8}$

Mogu li se školski rječnici hrvatskoga jezika svesti pod tu definiciju?

U Hrvatskoj su za stariji osnovnoškolski i srednjoškolski uzrast dosad objavljena tri rječnika koja u naslovu imaju pridjeve školski i hrvatski:

a) 1998. Hrvatski školski rječnik (Mijo Lončarić i Ante Bičanić), Profil;

b) 2012. Školski rječnik hrvatskoga jezika (Matea Birtić i dr.), Institut za hrvatski jezik i jezikoslovlje i Školska knjiga;

c) 2015. Anićev školski rječnik hrvatskoga jezika (priredili Ivo Pranjković i Lada Badurina), Znanje.

6 Jedno zanimljivo istraživanje pokazuje da je dubrovački varijetet najzastupljeniji nestandardni varijetet u materijalima za predmet Hrvatski jezik od 2014. do 2016. godine, no i on čini tek jednu desetinu gradiva (Matković 2016:55). Tu valja primijetiti da vjerojatno nije slučajno da dubrovačkog idioma ima najviše jer je on u svojoj osnovici vrlo sličan hrvatskome standardnom jeziku, dio je njegovih gramatičkih, ali i kulturnih temelja: njime je u renesansno doba ispisana impozantna književnost kojom se hrvatska kroatistika s razlogom ponosi. Kako je jedan od postulata ideologije standardnoga jezika neumorno dokazivati njegovu starost, tradiciju i što slavniju prošlost (Vogl 2012:19-20), ne čudi da su dubrovačke književnojezične teme zastupljenije u programu predmeta Hrvatski jezik od ostalih hrvatskih nestandardnih jezičnih tema.

7 Dokument Kurikulum nastavnog predmeta Hrvatski jezik za osnovne škole i gimnazije zbog vremena objave (2019) nije mogao utjecati na sastavljače školskih rječnika hrvatskoga jezika pa o njemu nećemo ovdje govoriti.

8 »Dictionaries for adolescents are designed for the needs of the school or college: their wordlists are based on what is found in schoolbooks, and their microstructural information is what teenagers need for their schoolwork «. 
Valja napomenuti da sva tri rječnika temelje svoje abecedarije na leksiku hrvatskoga standardnog jezika, što ističu tek u uvodu, dok naslovom na koricama zavode na krivi trag (v. bilješku 8).

Prvi je školski rječnik (Lončarić-Bičanić 1998) pravopisno-gramatički i kao takav ne donosi značenja riječi nego mu je cilj da učeniku olakša savladavanje problematičnih fonološko-morfoloških mjesta jezičnoga standarda. Autori ne navode iz kojeg su korpusa vadili riječi.

Drugi rječnik (Birtić i dr. 2012) sadrži približno 30000 natuknica. U dva predgovora autori iznose različite informacije o korpusu na kojem se rječnik temelji. Radoslav Katičić govori da se abecedarij temelji na školskom gradivu, dok Dunja Brozović Rončević daje naslutiti da se odustalo od te ideje i da se napravila nova koncepcija rječnika u Institutu za hrvatski jezik i jezikoslovlje (Predgovor, IX). Nadalje se u Uvodu potvrđuje da je rječnik temeljen na Hrvatskome jezičnom korpusu koji je sastavnica Hrvatske jezične riznice (Uvod, XII). Na mrežnim stranicama Instituta za hrvatski jezik i jezikoslovlje ne pronalazimo popis djela od kojih je sastavljena Hrvatska jezična riznica, stoga ne možemo znati jesu li i u kolikoj mjeri, u rječniku koji se korpusno na njoj temelji, zastupljeni školski sadržaji. Pitanje je stoga, uklapa li se koncepcijski (odabirom natuknica) Institutski rječnik u ideju o školskome rječniku kako ga definira Béjoint.

Prema mišljenju tvoraca dječjeg jezičnog korpusa s Oxforda: » ... dječji rječnici ne bi trebali biti sažeti rječnici za odrasle: > ...dječji rječnik temeljen na korpusu za odrasle neće odraziti jezik kojem su djeca izložena toliko precizno koliko rječnik temeljen na dječjem korpusu« «. ${ }^{9}$ (Wild, Kilgariff, Tugwell 2012:206).

U našem je istraživanju $u$ fokusu interesa treći, ujedno najrecentniji, Anićev školski rječnik (Anić [Pranjković-Badurina] 2015). Za razliku od Institutskog prethodnika, Anićev školski rječnik ima manji broj natuknica, njih oko 17000, jer priređivači smatraju da srednjoškolac i student barataju tolikim leksikonom (isto, VIII). Okosnicu rječnika čini leksik koji se pojavljuje u školskim udžbenicima, po prilici 10500 riječi i te su natuknice obilježene zvjezdicom. Zatim je u rječničku nomenklaturu, po izboru priređivača, dodano približno 6500 riječi iz opće kulture. Godine 2006. oformljena je radna skupina koja je iščitavala udžbenike i ekscerpirala riječi, a 2013. godine popis je ažuriran. U predgovoru je istaknuto da rječnik sadrži ponešto regionalnog i razgovornog leksika za koji priređivači smatraju

9 »...children's dictionary should not be abbreviation of adult's dictionary: >...a children's dictionary based on an adult's corpus will not reflect the language that children are exposed to as accurately as a children's dictionary based on a children's corpus « 
da se udomaćio i da je raširen, i za koji nema standardnojezičnog ekvivalenta, no priređivači također napominju da je Anićev školski rječnik bliži normativnome nego opisnome rječniku (isto, VII).

U središnjem dijelu rada istražit ćemo u kojoj je mjeri regionalni i razgovorni leksik kojemu su učenici osnovnih škola bili izloženi na satovima Hrvatskoga jezika - čitanjem hrvatskih čitanki - uvršten u Institutski i Anićev školski rječnik i što to govori o hrvatskoj leksikografiji namijenjenoj školskom uzrastu djece.

\section{Metode i ciljevi istraživanja}

Za potrebe istraživanja pregledane su dostupne hrvatske čitanke za više razrede osnovnih škola triju različitih nakladnika: Profil (Dveri riječi 5, 7, 8), Ljevak (Hrvatska čitanka V, VI, VII, VIII) i Školska knjiga (Krila riječi 5, 6; Iz priče u priču 5, 6, 7, 8), koje su objavljene i korištene u nastavi u periodu od 2006. do 2013. godine. Ta su izdanja nastala nakon donošenja Nastavnoga plana i programa iz 2006. te se očekuje da su s njime i usklađena, a trebala su biti ekscerpirana kao dio korpusa i za Institutski i za Anićev školski rječnik.

Kako je riječ o čitankama koje su se koristile prije mnogo godina, neke od njih nisu lako dostupne pa su u istraživanju izostale čitanke za pojedine razrede. To, vjerujemo, ipak nije utjecalo na konačni rezultat istraživanja kojim se željelo dobiti opći uvid u stanje stvari: odnos školskog rječnika i leksika koji je dijelom školskog gradiva. Vrijedi napomenuti da se u istraživanju pazilo na to da budu zastupljene čitanke svih triju ondašnjih izdavača: Profila, Ljevaka i Školske knjige. U konačnici je pregledano trinaest čitanki. ${ }^{10}$

Iz čitanki su potom izdvojene potvrde nestandardnog leksičkog sloja koji se obično tumači na marginama pod naslovom »Rječnik « (Iz priče u priču; Krila riječi); "Manje poznate riječi« (Hrvatska čitanka) ili bez naslova (Dveri riječi). Iznimno se u čitankama Dveri riječi za 7. i 8. razred na kraju donosi glosar »Manje poznate riječi i izrazi« iz kojeg je također ekscerpirana građa.

Naposlijetku je provjereno o kojem je i kakvom leksičkom sloju riječ te je li on uvršten u spomenute školske rječnike. Ako jest, u kojoj mjeri.

Nakon provedene analize, usporedbe izdvojenog "marginalnog" leksika ${ }^{11}$ iz hrvatskih čitanki s abecedarijima Institutskog i Anićeva školskog

\footnotetext{
10 Vidi detaljnije bibliografske podatke na kraju rada.

11 Taj je leksik marginalan i u doslovnom i, kako ćemo pokazati, u prenesenom
} 
rječnika, u raspravi se komentiraju rezultati istraživanja te se daju sugestije budućim priređivačima školskih rječnika hrvatskoga jezika.

\section{Rezultati analize}

Analiza je pokazala da se na marginama hrvatskih čitanki, koje sadrže uglavnom beletrističke tekstove, tumače riječi koje okvirno možemo podijeliti u nekoliko grupa. Velik je broj dijalektizama i regionalizama na svim jezičnim razinama, zatim ima mnogo žargonizama, slenga i kolokvijalnih izraza, a ne manjka ni posuđenica i tuđica - što regionalnih, što općeproširenih. Nađu se na čitanačkim marginama i arhaizmi, ali i novije riječi koje su ušle u hrvatski jezik i književnost s dolaskom modernih tehnologija.

U nastavku se daju primjeri ekscerpiranog leksika sortiranog po spomenutim grupama uz napomenu da cilj sortiranja nije matematički precizno razvrstavanje leksema, nego dobivanje opće slike o kakvu je leksiku riječ:

\section{1. dijalektizmi / regionalizmi}

U prvu skupinu ubrajamo leksičke potvrde iz svih triju narječja hrvatskoga jezika koje se nalaze u književnim tekstovima iz čitanki. Tu smo ubrojili dijalektizme koji se razlikuju od standardnojezičnih leksičkih ekvivalenata na bilo kojoj jezičnoj razini, kao i posuđenice koje su činjenicom pojedinih hrvatskih govora i dijalekata, a ušle su i u hrvatsku književnost: ${ }^{12}$

1.1. fonološki dijalektizmi / regionalizmi: 'aps 'zatvor', barzo 'brzo', besida 'riječ', bin 'bih', bisan 'bijesan', blešči 'bliješti', bormeš 'bogme', blesne 3. 1. jd. prez. 'bljesne', cvetje 'cvijeće', cvici 'cvjetovi', čarčki $\mathrm{N} \mathrm{mn.} \mathrm{'cvrčci',}$ čarna 'crna', ćer 'kćer', dalko 'daleko', darvo 'drvo', dašćice 'daščice', denes 'danas', dica 'djeca', did 'djed', do 'dao', dojde 'dođe', duvan 'duhan', $f$ ' 'u', goska 'guska', hrdjavi 'hrđavi', ijada 'hiljada', itak 'ipak', itros 'jutros', izresti 'izrasti', joblak 'oblak', joči 'oči', jošće 'još', ka 'kao', kaleb 'galeb', kesno 'ka$\mathrm{sno}^{\prime}$, ketač 'kotač', krepil glag. prid. r. 'osnaživao', labutovi 'labudovi', lito 'ljeto', naranža 'naranča', nijesu 3. 1. mn. 'nisu', pital glag. prid. r. 'pitao', pivac 'pijevac', plava 3. 1. jd. 'pliva', po julican L mn. 'po ulicama', prosida 'prosijeda', restu 3. 1. mn. 'rastu', smardlivi 'smrdljivi', snaše 'snahe', son 'sam', sonce 'sunce', soza 'suza', spušča 'spušta', sreča 'sreća', svičor 'svjećar na brodici', svioni 'svileni', svitle 'svijetle', š 's', ščiple 3. 1. jd. prez. 'štipa', šepčeju

značenju.

12 Značenja izdvojenih leksema donose se kao u čitankama neovisno o tome što su ponekad u neskladu sa značenjima koja se daju u rječnicima hrvatskoga jezika. 
3. 1. jd. prez. 'šapću', tenek 'tanak', teplo 'toplo', veter 'vjetar', vrebac 'vrabac', vridni 'vrijedni', vu 'u', vugli 'uglovi', vuho 'uho', vura 'ura, sat', vužge 'upali, zapali' i sl.

1.2. morfološki dijalektizmi / regionalizmi: baretun I jd. 'kapom', barkih $\mathrm{G}$ mn. 'barka', bin 'bih', brigah $\mathrm{G}$ mn. 'briga', brodi $\mathrm{N}$ mn. 'brodovi', dračan $\mathrm{D}$ mn. 'dračama', lečo 3. 1. mn. 'lete', mater $\mathrm{N}$ jd. 'majka', molju 'molim', mučidu / mučiju 3. 1. mn. 'šute', na keh L mn. m. r. 'na kojima', na njon L jd. ž. r. 'na njoj', naju A mn. 'nas', po dvoriman L mn. 'po dvorovima', po tvoji L ž. r. 'po tvojoj', pogleč 2. 1. jd. imp. 'pogledaj', pomoga glag. prid. r. 'pomogao', poznavam 1. 1. jd. prez. 'poznajem', putih L mn. m. r. 'putevima', široken D jd. m. r. 'širokom', spiju 3. 1. mn. prez. 'spavaju', široken D jd. m. r. 'širokom', škripjedu 'škripe', tijeli D jd. 'tijelu', veliju 3. 1. mn. 'kažu, govore', vratijeh 'vratima' i sl.

1.3. tvorbeni dijalektizmi / regionalizmi: dišeča $\mathrm{N}$ jd. ž. r. 'mirisna', gorše 'gore', grozdek' grozdić', kašnje 'kasnije', laglje 'lakše', lipji 'ljepši', maloprvo 'maloprije', obavita 'obavijena', oslek 'magarčić', rajše 'rađe', rubnjak 'rubnik', slajše 'slađe', vela 'velika' i sl.

1.4. leksički dijalektizmi / regionalizmi: ajkati 'jadikovati', ambrela 'kišobran', avlija 'dvorište', babo 'otac', bakandža 'čizma', balun 'lopta', barba 'u obraćanju djece stricu ili starijima', basta 'dosta', bašča/bašća 'vrt', bostan 'dinje i lubenice', beštimal 'psovao', birtija 'gostionica', bumbeta 'žarulja', bur$k a$ 'ogrtač koji pokriva čitavo tijelo s malim mrežastim izrezom za oči', ča 'što', čador 'šator', čakšire 'hlače', čika 'u obraćanju djece stricu ili starijima'; daidža 'ujak', dekla 'djevojka', divanit 'govoriti', drobn 'sitan, mali', drum 'cesta', dženet 'raj', đulistan 'ružičnjak', fačuk 'nezakonito dijete', fijolica 'ljubičica', fkanjček 'prevarant', flundra 'bludnica', frajla 'gospođica', fukara 'sirotinja', ganc 'posve', gizda 'ljepota ures', grosmama 'baka', grostata 'djed', gruntati 'razmišljati', gušt 'užitak', hanuma 'gospođa, supruga', hartija 'papir', hiža 'kuća', izila 'pojela', jaketa 'jakna', jalnuš 'zavidnik', japa 'otac', jaran 'prijatelj', kača 'zmija', kadija 'sudac', kaic 'mali čamac', kaj 'što', kajsija 'marelica', kala 'ulica', kampanel 'zvonik', kantati 'pjevati', kmica 'mrak', kozoderec 'sjeverni vjetar', kupica 'čaša', lancun 'plahta', libar 'knjiga', lukati 'viriti', macuol 'čekić', melja 'brašno', mendula 'badem', muka 'brašno', mustači 'brkovi', muž 'seljak', namrijeti 'umalo umrijeti', nanule 'natikače s drvenim potplatom', narisati 'nacrtati', nevera 'oluja', nigdar 'nikad', nonić 'djed', oblok 'prozor', opravica 'haljinica', osao 'magarac', otalen 'odatle', pače 'štoviše', pajcek 'svinja', pajdaš 'prijatelj', papa 'otac', pape 'otac', pariti se 'činiti se', pasala 'prošla', patri se 'priliči se', pazar 'sajam', pendžer 'prozor', penezi 'novac', pipa 'lula', pir 'svadba', pjaca 'trg', ponistra 'prozor', porat 'luka', postol/postola 'cipela', pot 'znoj', pot 'put', poteknuti 'dodati drva u 
peć', potepuh 'skitnica', potrefit 'pogodit', pramalet 'proljeće', primaliće 'proljeće', protuletje 'proljeće', punta 'rt, vrh', rabota 'težak posao', raca 'patka', re vera 'zaista', salaš 'seosko imanje', scufano 'poderano, oštećeno', sevdah 'ljubav, ljubavna čežnja', sleme 'vrh brda', sokak 'ulica', soldat 'vojnik', stat 'stanovat', svatovac 'svadbena pjesma', šjor 'u obraćanju djece stricu ili starijima', škatulja 'kutija', škoj/školj 'otok', škornje 'čizme', škrlak 'šešir', škura 'tamna', šoldi 'novac', šolja 'šalica', špancirati 'šetati', špigeta 'vezica za cipele', što 'tko', tramontana 'vjetar', utaman 'uzalud', vala 'zaista', vapor 'parobrod', varoš 'manje mjesto', vašar 'sajam', več/većlveće/većma 'više', veštit 'odijelo', Vuzem 'Uskrs', zač 'zašto', zajec 'zec', zajik 'jezik', zakaj 'zašto', zakunjat 'zadrijemati', zero 'malo' , zi 'iz', žniranci 'vezice za cipele', žurnal 'časopis' i sl.

1.5. semantički dijalektizmi / regionalizmi: gaće 'hlače', grub 'ružan', stiščem se 'privijam se', stat 'stanovati' i sl.

\section{2. žargonizmi / sleng / kolokvijalni izrazi}

U drugu skupinu uvrstili smo izraze koji su ušli u hrvatsku književnost i u čitanke hrvatskoga jezika za više razrede osnovnih škola, a pripadaju slengu i žargonu, to jest, kolokvijalne su naravi. ${ }^{13}$ Među njima također ima mnoštvo posuđenica i tuđica, kao i novijih riječi.

Evo nekoliko primjera:

bipnuti 'učiniti zvuk na kompjuteru', biznismen 'polovni čovjek', brand 'robna marka', buksa 'zatvor', cool 'izvrsno', cool 'miran, suzdržan', cucak 'pas, psic', dekintiran 'koji je bez novaca', delete 'brisati', dimi 'nestani', etvas 'nešto', fakat 'stvarno', fiksna ideja 'opsesivna misao', fotka 'fotografija', frajer 'mladić', gajba 'soba, stan', gastarbajter 'naši ljudi na privremenom radu u Njemačkoj', gentleman 'otmjen čovjek, gospodin', grunge 'žanr američke rock-glazbe', guba 'jako dobro', halbe 'pola', ini 'ostali, drugi', izgruhan 'izubijan', kelnerica 'konobarica', kiks 'pogreška', klipan 'neotesanac', klipsati 'dugo hodati', klopa 'hrana', kokotica 'vrsta frizure', komad 'žena, djevojka', kompić 'računalo', košaretina 'odbijanje osobe suprotnog spola', kulja 'jedinica', kužiti 'razumjeti', landrati 'bezbrižno se skitati', lange 'dugo', lemati 'tući', macan 'čvrst, snažan muškarac', macho 'pravi, tipičan muškarac', maher 'spretan čovjek', marte 'vrste čizama', mator 'star', minus 'dug na bankovnom računu', mrš!! 'odlazi!', mulac 'klinjo', nabasati ‘slučajno naići', najhaj 'najbolji', nick 'nadimak', nikeice 'vrsta tenisica', njupati 'jesti', O.K. 'sve u redu', operutati 'pokrasti', ošeprtljiti se 'zbuniti se', otpilila me 'otpravila

13 Uzimamo najširu definiciju žargonizama, slenga i kolokvijalnih izraza kao leksika koji pripada jeziku pojedinih struka ili jeziku mladih, to jest, ne pripada hrvatskome standardnom jeziku (usp. npr. Skelin Horvat 2017:6, bilješka 4, isto:97). 
me bez obavljena posla', pacer 'nespretnjakovic', pandur 'policajac', papak 'noga', papak 'primitivac', pardonček 'oproštenje', popaliti 'ukrasti', pretpotopni 'staromodan', prokljuviti 'shvatiti', riboni 'djevojke', rođkas 'rođendan', sentiš 'lagana ljubavna glazba', skockati se 'dotjerati se', skompale glag. prid. r. ž. r. 'sprijateljile', skužiti 'razumjeti', spika 'razgovor', stara 'majka', stari 'otac', supercool 'vrlo dobro, izvrsno', škija 'krijumčareni duhan', škvadra 'društvo', šnita 'kriška', šora 'tučnjava', šrajben 'pišem', štimung 'raspoloženje', šut 'injekcija droge', tata-mata 'pravi majstor', telkač 'televizor', trip 'stanje nakon uzimanja droge', trokeljati 'govoriti gluposti', trta 'strah', tulumiška 'tulum, zabava', tužakati 'često tužiti bez povoda', ukebati 'uhvatiti', uvaljati 'dati', vjetrenjast 'onaj koji zanemaruje obaveze i dužnosti', ziher 'sigurno', zvekan 'glupan, budala' i sl.

\section{3. arhaizmi / knjiški ekspresivni leksik}

Treću skupinu marginalnog čitanačkog leksika čine arhaizmi i knjiški ekspresivni leksik kojim su ispisane starija i novija hrvatska književnost, to jest oni njezini segmenti koji su na temelju Nastavnoga plana i programa iz 2006. ušli u čitanke za predmet Hrvatski jezik.

Evo nekoliko primjera takvih potvrda: čest 'dio', dinar 'jedinica novca', drug 'u socijalizmu muškarac', gartlic 'vrt', groš 'sitan novac', grundov$c i$ 'dječaci Pavlove ulice koji čuvaju grund', hvat 'mjera od četiri kubna metra', illustrissimus 'naziv za feudalnu gospodu, presvijetli', jazik 'jezik', jur 'još', kruna 'novčana jedinica u Austro-Ugarskoj', luna 'mjesec', ljuveni 'ljubavni', tezoro 'blago', uza trage 'natrag', uze 'ropstvo, okovi', užgat 'zapaliti' i sl.

\section{4. frazemi}

U posljednju provizornu skupinu svrstavamo nekoliko frazema pronađenih u promatranu korpusu: imati radi 'voljeti', imati smolu 'imati peh', mile-lale 'sad ovako, sad onako', nisi neg zinije na svit 'tek si se rodio'; prišiti ćušku 'ošamariti', vidi mi se 'čini mi se' i sl.

Pobrojani leksik nalazi se među 1591 leksičkom jedinicom ekscerpiranom s margina trinaest promatranih čitanki hrvatskoga jezika. Taj leksik nije činjenicom suvremenog hrvatskog standardnog jezika, no dijelom je, kako vidimo, hrvatske književnosti koja se obrađuje u nastavi u višim razredima osnovne škole. Dio tog leksika zasigurno je poznat đacima iz pojedinih hrvatskih govora, ovisno o podneblju iz kojeg dolaze, dio možda znaju iz medija i društvenih mreža - osobito novije riječi, sleng i žargonizme - no jedan dio zasigurno im je sasvim neproziran i stran te im je objaš- 
njenje potrebno. Na primjer, đacima iz južne Hrvatske dobro bi došlo tumačenje riječi snočka 'sinoć' iz pjesme Miroslava Dolenca Dravskog, dok bi djeci iz sjeverne i istočne Hrvatske dobro došlo tumačenje riječi ponistra 'prozor' i sl. Marginalni glosari su stoga praktično pomagalo za nastavu, no u mnogobrojnim slučajevima nisu dostatni jer uglavnom tumače riječ samo u obliku u kojem se ona pojavljuju u kontekstu, bez da se ponudi kanonski oblik i bez odrednice kojem leksičkom sloju riječ pripada, npr. cvici 'cvjetovi', do 'dao'. Također, na marginama se ne obrađuje polisemija, niti se izdvajaju značenjske finese, jer tomu margine i ne mogu služiti. Drugim riječima, marginski su glosari praktični, ali često šturi i nedovoljni za razumijevanje određena leksika i raslojenosti hrvatskoga jezika u cijelosti. U njima su također česte i pogreške o čemu će kasnije biti više riječi.

Sada dolazimo do zanimljivog dijela. Usporedbom ekscerpirana nestandardnog leksika iz hrvatskih čitanki s abecedarijima (popisima natuknica) u školskim rječnicima otkrili smo da je u Institutski školski rječnik ušlo svega 76 nestandardnih leksema, a u Anićev školski rječnik 62, od ukupno 1591 jedinice ekscerpiranog nestandardnog leksika. ${ }^{14} \mathrm{U}$ postocima to je 4,7\% u prvome rječniku, odnosno 3,7\% u drugome, s time da je Institutski rječnik po ukupnom broju natuknica gotovo dvostruko veći od Anićeva. Spomenute brojke otvaraju niz pitanja: treba li školski rječnik sadržavati leksik s kojim se učenik susreće tijekom obrazovnog procesa, dakle i onaj iz hrvatskih čitanki? Ako treba, zašto toliki leksik iz hrvatskih čitanki (= iz hrvatske književnosti), nije ušao niti u Institutski, niti u Anićev školski rječnik?

\section{Rasprava}

Postotak od 4,7\% to jest 3,7\% nestandardnog leksika koji je iz promatranih čitanki ušao u školske rječnike, zaista je malen. Nisu ušle niti riječi koje se ponavljaju na čitanačkim marginama više puta: bašča (3), ča (8), čez (10), črni (6), ćutim (4), di (gdje), drob(a)n (5), drum (4), gresti (7), jur (4), kaduna (4), ki (5), kmica (5), libar (3), ni (5), pendžer (3), poje (5), ponistra (3), pot (4), pozabi (5), sarce (3), sem (sam), sim (4), škoj (3), tić (3), v (6), varit (4), veter (3), vse (7), zač (6), zajec (3), zdigli (3) itd. To jedino može značiti da su te leksičke jedinice namjerno preskočene prilikom ekscerpiranja građe iz školskih materijala za školski rječnik. Zašto su autori/priređivači preskočili dobar

14 Nas je u ovom radu prvenstveno zanimalo koliko je nestandardnog leksika iz hrvatskih čitanki ušlo u školske rječnike hrvatskoga jezika, a za one kojima bi bilo zanimljivo vidjeti koji je leksik postao dijelom tih rječnika dajemo popis u tablici na kraju rada. 
dio nestandardnog leksika iz školskih materijala? ${ }^{15}$ Zasigurno razlog nije u manjku prostora, jer Institutski rječnik ima ukupno 30000 natuknica, a priređivači (ili izdavač) Anićeva rječnika samoinicijativno su dodali 6446 leksičkih jedinica koje nisu našli u školskim materijalima, a drže ih potrebnima za opću kulturu i naobrazbu (Anić [Pranjković-Badurina]:VIII). Smatramo da su u pozadini takva postupanja purizam i ideologija standardnoga jezika prema kojoj samo standardnojezični varijetet zaslužuje biti dijelom obrazovnog procesa. Ispuštanjem (engl. erasure, v. Irvine i Gal 2000:38) većine nestandardnog leksika indirektno se učenicima poručuje da taj leksički sloj ne moraju znati, niti se njime trebaju zamarati, jer on nije dovoljno vrijedan da uđe u školski rječnik - čak niti u Anićev školski rječnik koji ima preporuku za uporabu Ministarstva znanosti, obrazovanja i sporta od 15. prosinca 2014. godine. Slijedno tomu, učenik bi i svoj mjesni govor i dijalektnu književnost mogao smatrati manje vrijednom i manje lijepom od one pisane standardnim jezikom.

Prilog 1. Riječi s margina čitanke Iz priče u priču 6, 50.

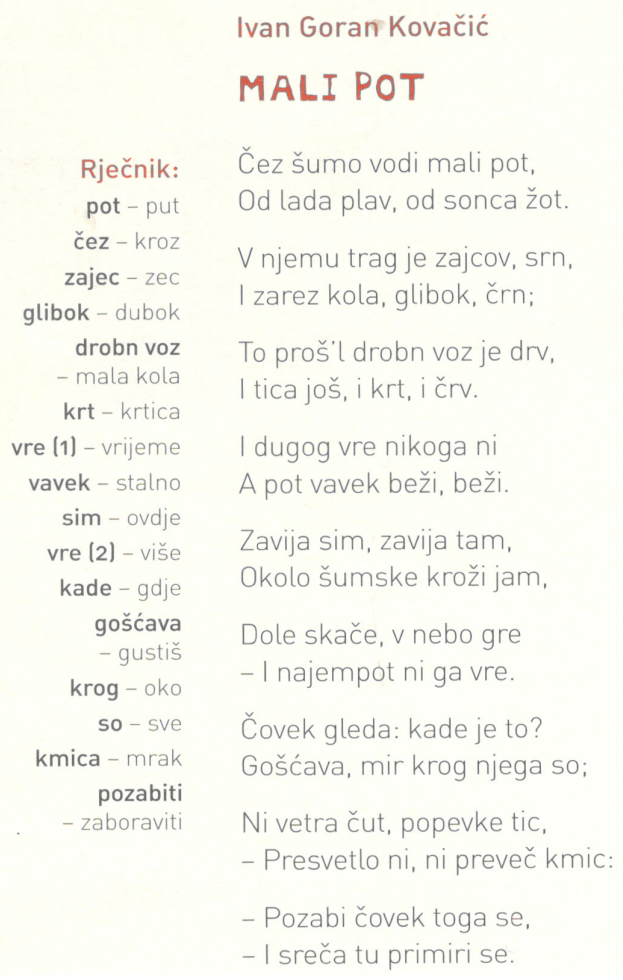

MALI POT

Čez šumo vodi mali pot.

Od lada plav, od sonca žot.

$\checkmark$ njemu trag je zajcov, srn,

I zarez kola, glibok, črn;

To prošl drobn voz je drv,

I tica još, i krt, i črv.

I dugog vre nikoga ni

A pot vavek beži, beži

Zavija sim, zavija tam

Okolo šumske kroži jam.

Dole skače, v nebo gre

- I najempot ni ga vre.

Čovek gleda: kade je to?

Gošćava, mir krog njega so:

Ni vetra čut, popevke tic

- Presvetlo ni, ni preveč kmic:

I sreča tu primiri se.

15 Preskočeno je više od 1500 leksičkih potvrda iz 13 čitanki za 4 razreda osnovne škole, a broj bi zacijelo bio veći kada bi se pregledalo sve nastavne materijale upotrebljavane od 2006. do 2013. godine. 
Osim toga što smo pronašli slabu zastupljenost nestandardnog leksika u školskim rječnicima, pri ekscerpiranju građe naišli smo na niz mjesta slabe obrade tog istog leksika na čitanačkim marginama. Primjerice, autori su zbunjeni oko značenja riječi vre iz pjesme Mali pot Ivana Gorana Kovačića (Grbaš i dr. 6, 2009:50) pa kažu da vre(1) znači 'vrijeme', što nije točno, a vre(2) znači 'više'. Zapravo je značenje priloga vre u toj pjesmi 'već, više'. Vjerojatno je autore dodatno zbunila pogreška u prijepisu same pjesme »I dugog vre nikoga ni« umjesto »I dugo vre nikoga ni«.

U oči upada nerazumijevanje kajkavskoga leksičkog sloja i u Kolarovoj Brezi gdje iz rečenice: »Kaj se tu protežeš? Valda si se dosta nacrkevala!...« autori na margini izvode sasvim neobičan, potpuno promašen, glagolski infinitiv nacrkevalati 'naspavati, izležavati' (Grbaš i dr. 8, 2009:63). ${ }^{16}$ Infinitiv od glagolskoga pridjeva nacrkevala glasi nacrkevati.

Prilog 2. Riječi s margina čitanke Iz priče u priču 6, 54.

\section{Dragutin Domjanić}

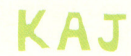

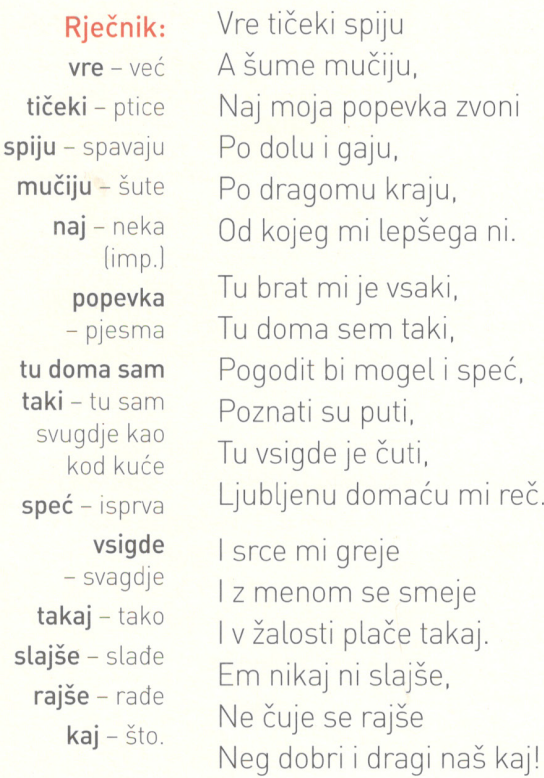

Glagolski prilog sadašnji glagola spati 'spavati': spećiz antologijske Domjanićeve pjesme Kaj također nije dobro shvaćen: »Tu brat mi je vsaki, / Tu doma sem taki, / Pogodit bi mogel i speć, / Poznati su puti, / Tu vsigde je

16 Kako su za potrebe istraživanja analizirani radni primjerci čitanki Iz priče u priču $5-8$, možemo se nadati da su spomenute greške uklonjene iz konačnih inačica. 
čuti, / Ljubljenu domaću mi reč.« Autori čitanke tumače speć kao 'isprva', umjesto 'spavajući'. Nadalje je vremenski prilog taki protumačen kao 'tu sam sougdje kao kod kuće', dok uistinu znači 'tu sam kod kuće uskoro, začas'.

Sve nam to govori da je kvalitetno tumačenje "manje poznatih riječi" iz hrvatske književnosti itekako potrebno hrvatskim đacima.

Budući da je hrvatska književnost, za razliku od hrvatskoga standardnog jezika, i u stvarnosti, a ne samo deklarativno, tronarječna, te obiluje i primjerima iz razgovornog stila hrvatskoga jezika, učenicima je za potrebe obrazovanja nužan leksikografski priručnik iz kojeg će dobiti informaciju o značenju pojedine riječi s kojom se susreću u čitankama i/ili u lektiri. Neovisno o tome je li koja riječ činjenicom standardnoga hrvatskog jezika, hrvatskih narječja / dijalekata, sociolekata, žargona, bila ona tuđica, primljenica ili nova riječ, i neovisno o tome što pojedinci o njoj misle i osjećaju, takav bi leksikografski priručnik trebao služiti kao izvor informacija, a ne kao leksički arbitar. To je osnova za praćenje i razumijevanje tekstova.

Navest ćemo jedan svijetao primjer iz školske leksikografije engleskoga jezika. Oxford School Dictionary temelji se na elektroničkome korpusu the Oxford Children's Corpus koji ima 30 milijuna pojavnica iz literature namijenjene djeci u dobi od 5 do 14 godina (Wild, Kilgarriff, Tugwell 2012:190). Tri četvrtine toga korpusa čini suvremena književnost, dječja književnost i mali potkorpus tekstova koji su napisala djeca. Sadrži i klasičnu dječju književnost koja ima arhaičniji jezik jer su te knjige dijelom kurikuluma. Zanimljivo je primijetiti da Oxford School Dictionary ne preže pred obradom dijalektizama pa tako u njemu nalazimo varijantne potvrde poput mom i mam uz mum 'mama' jer su to ostvaraji koji su poznati djeci u pojedinim predjelima Ujedinjenog Kraljevstva (Banerji i dr. 2013:317).

Slijediti dobre primjere nije sramota pa bismo i mi mogli djelovati $u$ smjeru oksfordskog školskog rječnika s ciljem da đake naučimo što znače koji nestandardni leksemi i gdje se upotrebljavaju. Konačno, neki se od njih u razgovornome jeziku upotrebljavaju daleko više od standardnojezičnih ekvivalenata: balun umjesto lopta u obalnoj Hrvatskoj, fakat umjesto zaista u Zagrebu i okolici, gušt umjesto užitak i sl.

Osim stranim uzorima možemo se okrenuti i vlastitoj jezičnoj povijesti te se prisjetiti Ivana Belostenca i njegova Gazofilacija, ${ }^{17}$ latinsko - hrvatsko-

17 Gazophylacium seu Latino-Illyricorum onomatum aerarium (Gazofilacij ili riznica latinsko-hrvatskih riječi), 1740. Sastoji se od latinsko-hrvatskoga dijela s oko 40000 natuknica i hrvatsko-latinskoga dijela s oko 25000 natuknica. 
ga rječnika u kojem pridjev illyricorum znači i štokavski i kajkavski i čakavski. Belostenec kraticom uz leksem bilježi područje na kojem se pojedini ekvivalent upotrebljava. ${ }^{18}$

Nakon svega rečenog, smatramo da je u hrvatskoj leksikografiji i dalje praznina na mjestu školskoga rječnika koji bi zadovoljavao potrebe đaka i tumačio leksik s kojim se đaci susreću tijekom nastave ili čitajući lektiru.

Bilo bi dobro izraditi nenormativni školski rječnik u kojem bi svoje mjesto našli ekvivalenti iz raznih hrvatskih govora koji su dijelom hrvatske književnosti, kao na primjer: ćaća, papa, pape, babo, japa, stari, tatko, matori 'otac, tata' ili striček, čika, barba, šjor i sl. kao 'dječji nazivi za starijeg muškarca' i sl. U takvu bi se rječniku našli ekvivalenti poput pramalet, primaliće, protuletje 'proljeće', ili oblok, pendžer i ponistra, kao i homografi poput pot 'znoj', pot 'put'.

Taj bi dakle rječnik trebao biti korpusno utemeljen na lektiri, dječjoj književnosti općenito i na nastavnim materijalima, a bilo bi praktičnije da bude elektronički, kako bi uz natuknice mogla biti karta s rasprostiranjem kojeg leksema, kao i zvučni zapis izgovora u pojedinom govoru. Odličan je primjer za usporedbu interaktivna čakavska čitanka Dragice Stanić, Čakavčica. ${ }^{19}$ Iz njezina uvodnog teksta, koji je vrlo afirmativno intoniran prema jezičnoj raslojenosti koja nas okružuje, možemo mnogo naučiti:

»Svima vama ljubiteljima čakavske besedi i onima koji je žele slušati, razumjeti, naučiti, a možda i govoriti! Sve riječi svijeta su čudesne i važne. Vode nas u stvarnost ili maštu. S njima se možemo poigrati, nekome ljubav iskazati, nešto i nekoga voljeti ili kuditi, nekoga pohvaliti ili s ljudima se bolje razumjeti. Pitamo li se sa što, kaj ili ča, svejedno su nam drage sve te riječi, samo što nas u neki drugi kraj svijeta vode, o tom svijetu nam govore ...« (Stanić 2015:9). Takav je pristup u skladu sa suvremenim istraživanjima koja pokazuju da »je najvažnije djetetu pokazati uvažavanje prema njegovom jeziku, onom kojim govori kada dolazi u školu« (Turza-Bogdan 2009:176, usp. i Chesire i Trudgill 1989:106).

18 Kajkavskim leksemima tumači latinske i njih ne obilježava posebno, uz čakavske i štokavske ekvivalente bilježi kraticu (D.), a uz slavonske turcizme kraticu (Scl.) ili (Scl. Turc.) (Vončina 1988:234).

19 Dragica Stanić: Čakavčica. Čakavska početnica i čitanka. Udžbenik za početno učenje kastavske čakavštine. Osnovna škola »Milan Brozović«, Kastav, 2015. E-udžbenik: www.cakavcica.com. 


\section{Zaključak}

U radu smo se pitali u kakvu su odnosu školski rječnici hrvatskoga jezika prema regionalnom i razgovornom leksiku koji se nalazi na marginama čitanki za Hrvatski jezik u višim razredima osnovne škole. Školski rječnik po definiciji bi trebao obraditi leksik s kojim se učenici susreću tijekom obrazovnog procesa te im služiti kao pomagalo u nastavi. $U$ fokusu našeg istraživanja bile su čitanke objavljene $u$ razdoblju od 2006. do 2013. godine jer su one, kao dio nastavnih materijala, usklađene s Nastavnim planom i programom iz 2006. u kojem je predviđen niz nestandardnojezičnih tema u nastavi hrvatskoga jezika, a s obzirom na vrijeme objave trebale su ući i u korpus za Institutski (2012) i Anićev školski rječnik (2015). Iz čitanki je ekscerpirano 1590-ak leksičkih jedinica koje nisu dijelom suvremenog hrvatskog standardnog jezika, ali su dijelom mjesnih govora, slenga i žargona zapisanih u hrvatskoj književnosti. Analiza je pokazala da je u Institutski školski rječnik ušlo tek 76 takvih leksema, a u Anićev školski rječnik 62 , što je u oba slučaja manje od 5\%. Kako razlog neuvrštavanja nestandardnih leksema nije prostorne prirode, ta Institutski je rječnik s 30000 natuknica velik sam po sebi, a priređivači Anićeva rječnika dodaju u rječničku nomenklaturu približno 6500 leksičkih jedinica prema vlastitu izboru, može se zaključiti da je u pozadini njihova odabira ideologija standardnoga jezika prema kojoj nestandardnim jezičnim elementima - ma koliko oni rašireni bili i mada ih upotrebljavali renomirani pisci - $\mathrm{u}$ obrazovanju zapravo nije mjesto.

S obzirom na to da su mnogobrojne studije pokazale da djeca razvijaju pozitivniji stav prema jeziku i sebi općenito ako se tijekom obrazovanja afirmativno odnosi prema govorima (bilo mjesnim, bilo gradskim) iz kojih potječu, smatramo da je hrvatskoj leksikografiji potreban školski rječnik koji bi bio inkluzivan prema leksiku koji je učenicima blizak iz vlastitih govora, ili s kojim se susreću čitajući tronarječnu hrvatsku književnost. Takav bi se rječnik trebao temeljiti na korpusu dječje književnosti i nastavnih materijala, trebao bi biti elektronički i interaktivan, sa zvučnim zapisima pojedinih leksema i kartama rasprostiranja. U konačnici, trebao bi promovirati jezičnu toleranciju i isticati jezično bogatstvo na teritoriju Republike Hrvatske. 
Bojana Schubert: Ni med cvetjem ni pravice! Obrada nestandardnog leksika u hrvatskim...

FILOLOGIJA 75(2020), 119-145

Prilog 3. Tablica leksema iz ekscerpiranih čitanki koji su ušli u školske rječnike. Točkom je označeno u kojem je rječniku leksem potvrđen.

\begin{tabular}{|c|c|c|c|}
\hline & $\begin{array}{l}\text { Regionalizmi, arhaizmi, tuđice, } \\
\text { posuđenice, žargonizmi, sleng, } \\
\text { knjiške ekspresivne riječi i sl. s } \\
\text { margina hrvatskih čitanki }\end{array}$ & $\begin{array}{l}\text { Potvrda u } \\
\text { Institutskom } \\
\text { školskom } \\
\text { rječniku, } 2012 .\end{array}$ & $\begin{array}{l}\text { Potvrda u } \\
\text { Anićevu } \\
\text { školskom } \\
\text { rječniku, } 2015 .\end{array}$ \\
\hline 1. & bajam 'badem' & • & \\
\hline 2. & balun 'lopta' & - & \\
\hline 3. & barba 'odrasla muška osoba' & $\bullet$ & $\bullet$ \\
\hline 4. & $\begin{array}{l}\text { bećar 'neoženjen, obijestan } \\
\text { momak' }\end{array}$ & $\bullet$ & \\
\hline 5. & bedak 'bena, budala' & & $\bullet$ \\
\hline 6. & begovica 'begova žena' & & $\bullet$ \\
\hline 7. & besjediti 'govoriti' & $\bullet$ & \\
\hline 8. & bež 'boja pijeska' & $\bullet$ & \\
\hline 9. & biznismen 'poslovni čovjek' & & $\bullet$ \\
\hline 10. & brlog 'neuredno i prljavo mjesto' & & $\bullet$ \\
\hline 11. & bubotak 'udarac šakom' & $\bullet$ & \\
\hline 12. & cifra 'brojka' & & $\bullet$ \\
\hline 13. & cinober 'crvena' & & $\bullet$ \\
\hline 14. & čardak 'kula' & $\bullet$ & $\bullet$ \\
\hline 15. & čehulja 'dio grozda' & $\bullet$ & \\
\hline 16. & ćaća 'otac' & & $\bullet$ \\
\hline 17. & ćakula 'govorkanje' & $\bullet$ & \\
\hline 18. & ćilim 'sag' & $\bullet$ & $\bullet$ \\
\hline 19. & ćošak ‘ugao' & $\bullet$ & $\bullet$ \\
\hline 20. & dažd 'kiša' & $\bullet$ & $\bullet$ \\
\hline 21. & $\begin{array}{l}\text { derviš 'pripadnik derviškog } \\
\text { reda, isposnik' }\end{array}$ & $\bullet$ & \\
\hline
\end{tabular}


Bojana Schubert: Ni med cvetjem ni pravice! Obrada nestandardnog leksika u hrvatskim...

FILOLOGIJA 75(2020), 119-145

\begin{tabular}{|c|c|c|c|}
\hline 22. & diler 'preprodavač droge' & & $\bullet$ \\
\hline 23. & dinar 'jedinica novca' & $\bullet$ & $\bullet$ \\
\hline 24. & drug 'u socijalizmu muškarac' & $\bullet$ & $\bullet$ \\
\hline 25. & drum 'cesta' & $\bullet$ & \\
\hline 26. & $d u z ̌ d$ 'mletački vladar' & $\bullet$ & $\bullet$ \\
\hline 27. & dvor 'dvorište' & $\begin{array}{l}\text { (nema u tom } \\
\text { značenju) }\end{array}$ & $\bullet$ \\
\hline 28. & đeram 'đerma' & $\bullet$ & \\
\hline 29. & fakin 'deran, mangup' & & $\bullet$ \\
\hline 30. & farba 'boja' & & $\bullet$ \\
\hline 31. & groš njem. 'sitan novac' & $\bullet$ & \\
\hline 32. & hašiš 'opojna tvar' & $\bullet$ & $\bullet$ \\
\hline 33. & herc 'srce' & $\bullet$ & $\bullet$ \\
\hline 34. & hiljadu 'tisuću' & $\bullet$ & $\bullet$ \\
\hline 35. & hljeb 'kruh' & $\bullet$ & $\bullet$ \\
\hline 36. & hodža 'islamski svećenik' & $\bullet$ & $\bullet$ \\
\hline 37. & $\begin{array}{l}\text { hvat 'mjera od četiri kubna } \\
\text { metra' }\end{array}$ & $\bullet$ & \\
\hline 38. & ini 'ostali, drugi' & $\bullet$ & \\
\hline 39. & kadija 'sudac' & $\bullet$ & \\
\hline 40. & kaić 'mali čamac' & $\bullet$ & $\bullet$ \\
\hline 41. & kalif tur. 'titula turskog sultana' & $\bullet$ & $\bullet$ \\
\hline 42. & kesa 'vrećica' & $\bullet$ & \\
\hline 43. & klinac 'muško dijete' & $\bullet$ & $\bullet$ \\
\hline 44. & klipan 'neotesanac' & $\bullet$ & \\
\hline 45. & klipsati ‘dugo hodati’ & & $\bullet$ \\
\hline 46. & klopa 'jelo' & $\bullet$ & \\
\hline
\end{tabular}


Bojana Schubert: Ni med cvetjem ni pravice! Obrada nestandardnog leksika u hrvatskim...

FILOLOGIJA 75(2020), 119-145

\begin{tabular}{|c|c|c|c|}
\hline 47. & kuljati 'sukljati' & & $\bullet$ \\
\hline 48. & kuš! 'umukni! zašuti!' & & $\bullet$ \\
\hline 49. & $l u c ̌$ 'svjetlo' & $\bullet$ & $\bullet$ \\
\hline 50. & ma 'usklik čuđenja' & $\bullet$ & \\
\hline 51. & majur 'imanje' & & $\bullet$ \\
\hline 52. & minaret 'visok toranj džamije' & $\bullet$ & $\bullet$ \\
\hline 53. & miting 'politički skup, zbor' & & $\bullet$ \\
\hline 54. & mješina 'trbuh' & $\begin{array}{l}\text { (nema u tom } \\
\text { značenju) }\end{array}$ & $\bullet$ \\
\hline 55. & mrs 'meso' & & $\bullet$ \\
\hline 56. & $m r s ̌$ 'odlazi' & $\bullet$ & \\
\hline 57. & murva 'dud' & $\bullet$ & \\
\hline 58. & musav 'prljav' & $\bullet$ & $\bullet$ \\
\hline 59. & naleći 'navaliti' & $\bullet$ & \\
\hline 60. & narisati 'nacrtati' & $\bullet$ & \\
\hline 61. & nastavati 'prebivati' & $\bullet$ & \\
\hline 62. & nevera 'oluja' & $\bullet$ & \\
\hline 63. & $\begin{array}{l}\text { njištati 'glagol kojim se } \\
\text { predočuje prodorno oglašavanje } \\
\text { konja' }\end{array}$ & $\bullet$ & \\
\hline 64. & obrnuti 'okrenuti' & $\bullet$ & $\bullet$ \\
\hline 65. & odapeti 'umrijeti' & & $\bullet$ \\
\hline 66. & $\begin{array}{l}\text { peljar 'pomorac koji vodi brod u } \\
\text { luku' }\end{array}$ & $\bullet$ & $\bullet$ \\
\hline 67. & pest 'šaka' & $\bullet$ & \\
\hline 68. & pir 'svadba' & & $\bullet$ \\
\hline 69. & $\begin{array}{l}\text { piroga 'čamac izduben u } \\
\text { komadu drveta' }\end{array}$ & $\bullet$ & \\
\hline 70 & pokoj 'mir, spokojstvo' & $\begin{array}{l}\text { (nema u tom } \\
\text { značenju) }\end{array}$ & $\bullet$ \\
\hline
\end{tabular}


Bojana Schubert: Ni med cvetjem ni pravice! Obrada nestandardnog leksika u hrvatskim...

FILOLOGIJA 75(2020), 119-145

\begin{tabular}{|c|c|c|c|}
\hline 71. & polip 'hobotnica' & $\bullet$ & \\
\hline 72. & pretpotopni ‘staromodni’ & & $\bullet$ \\
\hline 73. & purgar 'građanin' & $\bullet$ & \\
\hline 74. & purger 'pogrdno za Zagrepčana' & & $\bullet$ \\
\hline 75. & raja 'običan svijet' & $\begin{array}{c}\text { (nema u tom } \\
\text { značenju) }\end{array}$ & • \\
\hline 76. & $\begin{array}{l}\text { reduša 'žena koja je zadužena za } \\
\text { čišćenje' }\end{array}$ & • & $\bullet$ \\
\hline 77. & rujno 'rumeno' & $\bullet$ & $\bullet$ \\
\hline 78. & rulja 'svjetina' & $\bullet$ & $\bullet$ \\
\hline 79. & ružiti 'štropotati' & & $\bullet$ \\
\hline 80. & salaš 'seosko imanje' & $\bullet$ & \\
\hline 81. & sapa 'dah' & $\bullet$ & \\
\hline 82. & sika 'oštar kamen uz more' & $\bullet$ & $\bullet$ \\
\hline 83. & slak 'biljka penjačica' & $\bullet$ & \\
\hline 84. & stara 'majka' & $\bullet$ & \\
\hline 85. & stari 'otac' & $\bullet$ & \\
\hline 86. & sura 'siva' & $\bullet$ & $\bullet$ \\
\hline 87. & $\begin{array}{l}\text { surfati 'pretraživati sadržaje na } \\
\text { internetu' }\end{array}$ & $\bullet$ & $\bullet$ \\
\hline 88. & $\begin{array}{l}\text { šindra 'drvena građa kojom se } \\
\text { pokriva krov' }\end{array}$ & & $\bullet$ \\
\hline 89. & $\begin{array}{l}\text { šmrkavac 'nezrela osoba, } \\
\text { balavac' }\end{array}$ & & $\bullet$ \\
\hline 90. & šugav 'neugodan' & $\bullet$ & $\bullet$ \\
\hline 91. & tovar 'magarac' & $\bullet$ & $\bullet$ \\
\hline 92. & trpeza 'stol za blagovanje' & $\bullet$ & \\
\hline 93. & $\begin{array}{l}\text { tuce 'dvanaest jednakih } \\
\text { istorodnih predmeta' }\end{array}$ & $\bullet$ & $\bullet$ \\
\hline 94. & $\begin{array}{l}\text { turban 'pokrivalo za glavu u } \\
\text { muslimana' }\end{array}$ & $\bullet$ & $\bullet$ \\
\hline
\end{tabular}


Bojana Schubert: Ni med cvetjem ni pravice! Obrada nestandardnog leksika u hrvatskim...

FILOLOGIJA 75(2020), 119-145

\begin{tabular}{|c|c|c|c|}
\hline 95. & tužakati 'često tužiti bez povoda' & $\bullet$ & \\
\hline 96. & ubav 'ljubak' & $\bullet$ & \\
\hline 97. & ura 'sat' & $\bullet$ & $\bullet$ \\
\hline 98. & utaman 'uzalud' & & $\bullet$ \\
\hline 99. & varoš 'manje mjesto' & $\bullet$ & \\
\hline 100. & voz 'kola' & $\bullet$ & \\
\hline 101. & zar 'veo za pokrivanje lica' & $\bullet$ & \\
\hline 102. & zaušnica 'šamar' & $\bullet$ & \\
\hline 103. & znamen 'znak' & $\bullet$ & $\bullet$ \\
\hline 104. & želva 'kornjača' & $\bullet$ & \\
\hline 105. & žniranci 'vezice za cipele' & & $\bullet$ \\
\hline
\end{tabular}

Izvori

Anić, Vladimir. 2015. Anićev školski rječnik hrvatskoga jezika. Prir. Pranjković, Ivo; Lada Badurina. Zagreb: Znanje.

Babić, Nada; Dinka Golem; Dunja Jelčić. 2007. Dveri riječi. Hrvatska čitanka za peti razred osnovne škole. Zagreb: Profil.

Babić, Nada; Dinka Golem; Dunja Jelčić. 2007. Dveri riječi. Hrvatska čitanka za sedmi razred osnovne škole. Zagreb: Profil.

Babić, Nada; Dinka Golem; Dunja Jelčić; Ivan Đurić. 2007. Dveri riječi. Hrvatska čitanka za osmi razred osnovne škole. Zagreb: Profil.

Bežen, Ante; Olga Jambrec. 2009. Hrvatska čitanka za V. razred osnovne škole. Zagreb: Ljevak.

Bežen, Ante; Olga Jambrec. 2009. Hrvatska čitanka za VIII. razred osnovne škole. Zagreb: Ljevak.

Birtić, Matea i dr. 2012. Školski rječnik hrvatskoga jezika. Zagreb: Institut za hrvatski jezik i jezikoslovlje - Školska knjiga.

Grbaš, Dijana; Sonja Tošić-Grlač; Tvrtko Vuković; Ivana Žužul; Tanja Vrvilo. 2009. Iz priče u priču. Hrvatska čitanka za peti razred osnovne škole. Radni primjerak. Zagreb: Školska knjiga.

Grbaš, Dijana; Sonja Tošić-Grlač; Tvrtko Vuković; Ivana Žužul; Jasmina Dvorski. 2009. Iz priče u priču. Hrvatska čitanka za šesti razred osnovne škole. Radni primjerak. Zagreb: Školska knjiga. 
Grbaš, Dijana; Sonja Tošić-Grlač; Tvrtko Vuković; Ivana Žužul; Tanja Vrvilo. 2009. Iz priče u priču. Hrvatska čitanka za sedmi razred osnovne škole. Radni primjerak. Zagreb: Školska knjiga.

Grbaš, Dijana; Sonja Tošić-Grlač; Tvrtko Vuković; Ivana Žužul; Jasmina Dvorski. 2009. Iz priče u priču. Hrvatska čitanka za osmi razred osnovne škole. Radni primjerak. Zagreb: Školska knjiga.

Jambrec, Olga; Ante Bežen. 2009. Hrvatska čitanka za VI. razred osnovne škole. Zagreb: Ljevak.

Jambrec, Olga; Ante Bežen. 2009. Hrvatska čitanka za VII. razred osnovne škole. Zagreb: Ljevak.

Lončarić, Mijo; Ante Bičanić. 1998. Hrvatski školski rječnik. Zagreb: Profil International.

Nacionalni okvirni kurikulum za predškolski odgoj i obrazovanje te opće obvezno i srednjoškolsko obrazovanje. 2011. Prir. Fuchs, Radovan; Dijana Vican; Ivan Milanović Litre. Zagreb: Ministarstvo znanosti, obrazovanja i športa RH.

Nastavni plan i program za osnovnu školu. 2006. Prir. Vican, Dijana; Ivan Milanović Litre. Republika Hrvatska. Zagreb: Ministarstvo znanosti, obrazovanja i športa.

Šojat, Anita i dr. 2007. Krila riječi. Čitanka za peti razred osnovne škole. Zagreb: Školska knjiga.

Šojat, Anita i dr. 2007. Krila riječi. Čitanka za šesti razred osnovne škole. Zagreb: Školska knjiga.

\section{Literatura}

Algeo, John. 1989. Dictionaries as seen by the educated public in Great Britan and the USA. Prir. Hausmann, F. i dr. Wörterbücher. Ein internationales Handbuch zur Lexikographie. Berlin: de Gruyter, 28-34.

Banerji, Nilanjana i dr. 2013. Oxford Children's Corpus: a Corpus of Children's Writing, Reading, and Education. Corpus Linguistics 2013 Abstract book, 315-318. http://ucrel.lancs.ac.uk/cl2013/doc/CL2013-ABSTRACT-BOOK.pdf (pristupljeno 15. 9. 2020.)

Béjoint, Henri. 2000. Modern lexicography: An introduction. New York: Oxford University Press.

Cheshire, Jenny; Peter Trudgill. 1989. Dialect and Education in the United Kingdom. Prir. Cheshire, Jenny; Viv Edwards; Henk Münstermann; Bert Weltens. Dialect and education. Some European Perspectives. Clevedon - Philadelphia: Multilingual Matters, 94-109. 
Daničić, Đuro. 1976. Ogled. Rječnik hrvatskoga ili srpskoga jezika. Dio 23: 2. zlotvor-žvuknuti: popis izvora, dodatak. Prir. Jedvaj, Josip i dr. Zagreb: Jugoslavenska akademija znanosti i umjetnosti.

Gorjanc, Vojko. 2017. Nije rečnik za seljaka. Prevela sa slovenačkog Majda Moličnik. Beograd: Biblioteka XX vek.

Hornberger, Nancy H. 2008. Encyclopedia of language and education. New York: Springer.

Irvine, Judith T.; Susan Gal. 2000. Language Ideology and Linguistic Differentiation. Prir. Kroskrity, Paul. V. Regimes of language: Ideologies, polities, and identities. Santa Fe: School of American Research Press, 35-84.

Katnić-Bakaršić, Marina. 2012. Između diskursa moći i moći diskursa. Zagreb: Naklada ZORO.

Maresić, Jela; Bojana Schubert. 2014. Kajkavski jezični izraz u djelima Frana Galovića. Fluminensia: časopis za filološka istraživanja, 26, 2, 25-40.

Matković, Jelena. 2016. Dubrovački idiom u nastavi Hrvatskoga jezika. Diplomski rad. Zagreb: Filozofski fakultet.

Milroy, Lesly; James Milroy. 1992. Social network and social class: Toward an integrated sociolinguistic model. Language in Society, 21, 1, 1-26.

Rječnik hrvatskoga kajkavskoga književnog jezika. 1984. - 2017. Dosad objavljeno 14 svezaka ( $a-$ seljanec). Zagreb: Hrvatska akademija znanosti i umjetnosti - Institut za hrvatski jezik i jezikoslovlje.

Schubert, Bojana. 2018. Senjani u Benešićevu rječniku iliti o lijevoj strani Rječnika hrvatskoga književnoga jezika od preporoda do I. G. Kovačića. Prir. Vukelić, Ana. 1. zbornik senjskog interdisciplinarnog simpozija »Zdravo ste nam, braćo, u kamenu Senju! (nova čitanja) «. Senj: Grad Senj, 111-133.

Skelin Horvat, Anita. 2017. O jeziku i identitetima hrvatskih adolescenata. Zagreb: Srednja Europa.

Spolsky, Bernard. 1978. Educational linguistics: An introduction. Rowley, Massachusetts: Newbury House Publishers.

Spolsky, Bernard; Francis M. Hult. 2008. The Handbook of Educational Linguistics. Blackwell Publishing Ltd.

Stanić, Dragica. 2015. Čakavčica. Čakavska početnica i čitanka. Udžbenik za početno učenje kastavske čakavštine. Kastav: Osnovna škola »Milan Brozović«. E-udžbenik www.cakavcica.com (pristupljeno 1. 9. 2018.).

Thomas, George. 1991. Linguistic Purism. London - New York: Longman. Turza-Bogdan, Tamara. 2009. Stavovi nastavnika o kajkavskome narječju. Hrvatski: časopis za teoriju i praksu nastave hrvatskoga jezika, književnosti, govornoga i pismenoga izražavanja te medijske kulture, 7, 1, 2009, 173-192. 
Turza-Bogdan, Tamara. 2011. Kajkavsko narječje i književnost u nastavnim planovima i programima. Prir. Bežen, Ante; Đuro Blažeka. I. međimurski filološki dani. Zagreb: Učiteljski fakultet Sveučilišta u Zagrebu, 183-191.

Turza-Bogdan, Tamara. 2013. Kajkavsko narječje u nastavi hrvatskoga jezika. Prilozi za osnovnoškolsku nastavu. Čakovec: Matica hrvatska ogranak Čakovec.

Vogl, Ulrike. 2012. Multilingualism in a standard language culture. Prir. Hüning, Matthias; Ulrike Vogl; Olivier Moliner. Standard Languages and Multilingualism in European History. Amsterdam: John Benjamins, 1-42.

Vončina, Josip. 1988. Jezična baština: lingvostilistička hrestomatija hrvatske književnosti od kraja 15. do početka 19. stoljeća. Split: Književni krug.

Wild, Kate; Adam Kilgarriff; David Tugwell. 2012. The Oxford Children's Corpus: Using a Children's Corpus in Lexicography. International Journal of Lexicography 26, 2, 190-218.

\section{Ni med cvetjem ni pravice! Analysis of non-standard lexic in Croatian obligatory readers and school dictionaries}

\section{Abstract}

Paper analyses standard language ideology in Croatia, with a special focus on educational system - obligatory readers and school dictionaries. In Croatia three dictionaries having the adjectives school and Croatian in their titles were published. We examined two of them: Školski rječnik published in 2012 by Institute of Croatian language and linguistics and Anićev školski rječnik published in 2015 by Znanje. The most interesting dictionary is the latest Anićev školski rječnik hrvatskoga jezika (Anić School Dictionary of the Croatian Language) (edited by Ivo Pranjković i Lada Badurina), because it has government recommendation for school purposes. Its editors stress that the core of the Dictionary (app. 10,500 words) is formed by the words featuring in school textbooks - and they are marked with an asterisk - and approximately 6,500 general culture words have been added. In 2006 they even formed a work team that read the textbooks in detail and sorted out the words, so in 2013 they updated the list. In the Preface they say that the dictionary contains some regional and colloquial vocabulary, which they consider to be in household use, widespread and which has no standard language equivalent.

We examined 13 readers published by three different publishers (Profil, Ljevak and Školska knjiga) during the period when two school dictionaries were made. We were interested in how much regional vocabulary, slang and jargon they generally contain and how they relate to it. That vocabulary is 
more or less successfully dealt with on the margins or inside quadrat frame footnotes below the texts (From the dictionary; Unknown words). We excerpted the regionalisms - kajkavisms, čakavisms, štokavisms, slang and jargon words and checked them up in Školski rječnik, 2012, and Anićev školski rječnik, 2015.

1591 lexemes have been excerpted, and only 76 of them entered Školski rječnik and 62 of them entered the Anićev školski rječnik - they make up less then 5 per cent of the total number of dictionary entries. In other words, the editors of school dictionaries just skipped the lexemes in the readers which they did not consider to be parts of the Croatian standard language and they did not include them into the school dictionaries.

Such a procedure raises several questions: How justified is it? What message does it send to children whose mother tongues are Kajkavian, Štokavian, Čakavian, or non-standard colloquial urban speeches? Why should a school dictionary be exclusively a normative dictionary? Especially if we take into account that Croatian literature is open to the vocabulary coming from all the three dialect groups and it also contains slang and jargon? Should the principal purpose of a school dictionary not be to explain the meanings of the words which a student comes across during his or her education? - all the words including the non-standard ones that the literature is written in?

We concluded that a non-normative school dictionary of the Croatian language should be written and it should be based on the corpus that includes reading lists, children's literature, both Croatian and foreign (translated), texts from schoolbooks and readers, because a child comes across them on a daily basis.

A Kajkavian person should be able to find in it the Čakavian and Štokavian forms he or she does not understand in literature, and the other way round.

That kind of school dictionary should promote language tolerance and demonstrate wealth and beauty of Croatian language in hole.

Ključne riječi: školski rječnici, čitanke za predmet Hrvatski jezik, nestandardni leksik, ideologija standardnog jezika

Keywords: school dictionaries, Croatian readers, non-standard lexemes, ideology of standard language 
